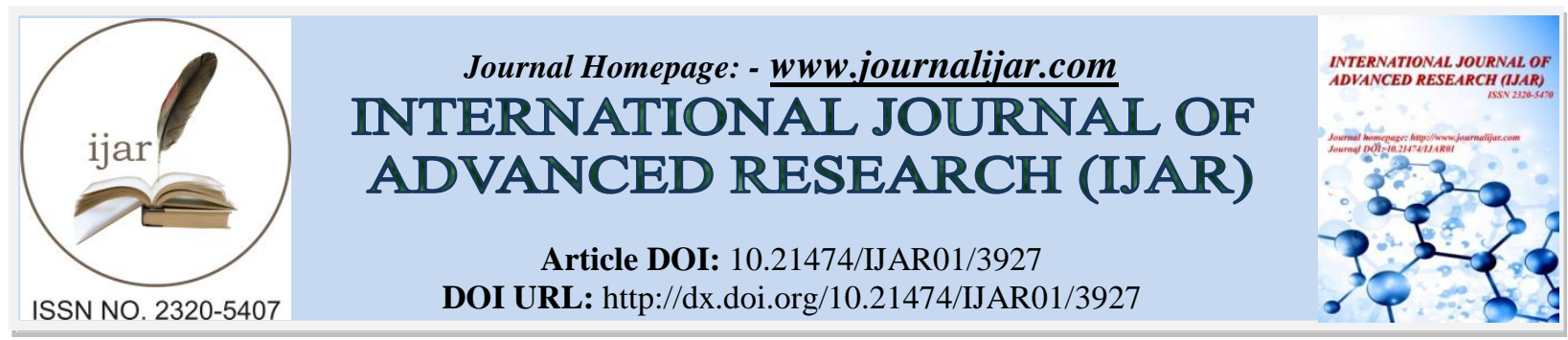

RESEARCH ARTICLE

\title{
EFFECTS OF TRICHANTERA LEAF MEAL AND FERMENTED LEAVES ON THE GROWTH PERFORMANCE AND CARCASS CHARACTERISTICS OF GROWER-FINISHER PIGS.
}

Elena M. Manaig, Ph. D.

Professor, College of Agriculture, Laguna State Polytechnic University (Siniloan Campus), Siniloan, Laguna, Philippines.

\section{Manuscript Info}

Manuscript History

Received: 11 February 2017

Final Accepted: 14 March 2017

Published: April 2017

Key words:-

trichantera leaf meal, fermented feed efficiency trichantera leaves, restricted feeding,

\begin{abstract}
A study involving three dietary treatments, namely, basal diet, $20 \%$ trichantera leaf meal and $20 \%$ fermented trichantera leaves, was undertaken to examine the effects on the growth and carcass characteristics of grower-finisher pigs. The experiment was conducted in a completely randomized design for 98 days with 18 eight-week old weanlings. The experimental diets were given in restricted feeding scheme with half of the amount in the morning and the other half in the afternoon. Total weight gain, average daily gain and feed efficiency were computed from data on initial and final body weights and feed consumption. The costs of feeds and weanlings and price of grown-out pigs were used in the computation of returns over weanling and feed cost. Based on the results, pigs fed with fermented trichantera leaves performed significantly better than the pigs fed the basal diet only and those fed with trichantera leaf meal in terms of total weight gain, average daily gain and feed conversion. There were also significant differences among treatment means in terms of feed cost $/ \mathrm{kg}$ gain and returns above weanling and feed cost. The highest advantage in terms of costs and returns was realized in using fermented trichantera leaves followed by using trichantera leaf meal. Therefore, trichantera leaves in leaf meal and fermented forms can be used efficiently with growing finishing pigs up to $20 \%$ of the diets.
\end{abstract}

Copy Right, IJAR, 2017,. All rights reserved.

\section{Introduction:-}

Swine raising is very popular in the Philippines and many Filipinos are venturing in this enterprise. The backyard pig producers dominate the local swine industry; about $64 \%$ of the total stocks were raised in backyard farms and the rest were in commercial farms (PSA 2016). Backyard pig production as a "Piggy Bank" concept represents the most basic financial strategy for most rural communities. It is a source of income that can be used for planned and emergency needs. However, pig farming is a capital-intensive practice and smaller-sized producers encounter financial constraints when it comes to access to feeds and quality breeding stocks, and to veterinary services (Costales et al., 2006). Feed and drug costs constitute $78 \%$ of the production cost in backyard swine farming (Aquino and Malazo, 2005). Therefore, to be able to sustain the enterprise, there is a need to reduce the cost of feed and one of the ways is to utilize locally available low-cost materials that can be used as feedstuff for pigs. Fodder crops are examples of such materials.

Corresponding Author:- Elena M. Manaig.

Address:- Professor, College of Agriculture, Laguna State Polytechnic University (Siniloan Campus), 
The potential use of different fodder crops had already been tested in some studies but results are still inconclusive. One of these fodder crops is Trichantera gigantea, also known as nacedero or madre de agua, which was introduced into the country from South America. It is a non-legume species of fodder tree that is adapted to Philippine condition. It grows well in a wide range of soil types and at elevations up to 1800 meters above sea level. When planted at a density of 20,000/ha, it can yield 40-60 tons of fresh foliage. It can be rejuvenated repeatedly and still produce the same or even higher yield. Its leaves contain 18-22\% crude protein on dry matter basis making it a potential protein source (dela Cruz, 2011). Trichantera can be easily propagated by cuttings; it has rapid growth rate, good regrowth ability, high stem-leaf ratio and ability to thrive even under unfavorable environmental conditionsome of the characteristics that should be considered when selecting fodder crop (Diaz, 2012).

Among the nutrients needed by animals, protein is the most expensive. Smallholder animal production efficiency is limited by the high cost and, sometimes, the lack of available commercial protein supplements (Martens, 2012). Different levels of crude protein content of Trichantera leaf meal had been recorded such as 26.30\% (Ly et. al, 2001), 23.9\% (Sarwatt et al., 2003, 20.1\% (Leterme, et al., 2006),18.21\% (Jaya et al., 2008) and 25\% (Martens, et al., 2012) on dry basis. These levels match or even exceed the level of crude protein that is needed in pig grower rations.

However, high level of crude protein in trichantera leaves does not guarantee its nutritional quality because of the fiber-bound nitrogen (Shayo and Uden, 1999) and enzyme inhibitors that reduce digestibility. There are processes in feed preparation that can improve digestibility. Diaz (2012) reported 3\% increase of true protein and 5-10 \% reduction of fiber upon fermentation of bagasse. With additional stirring, the increase was $11 \%$ for crude protein and $20 \%$ for organic matter digestibility. Other ways of increasing digestibility of fodder are chopping, grinding and heating which are done when preparing leaf meals. The present study investigated the effects of trichantera leaves in leaf meal and fermented forms on the growth and carcass characteristics of grower-finisher pigs.

\section{Methodology:-}

An experiment involving three treatments was conducted in a farmer's backyard farm following a completely randomized design. Each treatment was replicated six times with one pig per replication. The treatments used are presented in Table 1. A total of 60-day old crossbreed weanlings was bought from a commercial piggery farm. Three large litters that were farrowed on the same date were selected. Three female and three male pigs that were almost of the same weight were selected from each litter. The pigs in one litter were randomly divided into three pairs of one male and one female. Then, the pairs were randomly distributed to the three treatments. The selection and pairing of pigs, and random distribution to the treatments done with the first litter were also done with the second and third litters. The pigs were housed in individual $1.0 \mathrm{~m} \times 1.5 \mathrm{~m}$ pens in open shed with cogon and bamboo leaves roofing. Each pen had flooring of 2 feet-thick sawdust litter dug on the ground, bamboo slats for enclosure and was provided with feeding trough and drinking nipple.

Table 1:- Treatments used in the experiment

\begin{tabular}{|c|l|l|l|}
\hline Treatment Label & \multicolumn{1}{|c|}{$\begin{array}{c}\text { Treatment } \\
\text { (Experimental Diet) }\end{array}$} & \multicolumn{1}{c|}{$\begin{array}{c}\text { Amounts used } \\
\mathrm{kg}\end{array}$} & $\begin{array}{c}\text { Dry Matter } \\
\mathrm{kg} / 100 \mathrm{~kg}\end{array}$ \\
\hline $\mathrm{T}_{1}$ & $100 \%$ basal & $100 \mathrm{basal}$ & 87.46 \\
\hline $\mathrm{T}_{2}$ & $80 \%$ basal $+20 \%$ TLM & $80 \mathrm{basal}+20 \mathrm{TLM}$ & $69.97+17.5=87.47$ \\
\hline $\mathrm{T}_{3}$ & $80 \%$ basal $+20 \%$ (FTL) & $80 \mathrm{basal}+64.8 \mathrm{FTL}$ & $69.97+17.5=87.47$ \\
\hline
\end{tabular}

The proximate analyses of the ingredients used are presented in Table 2. The moisture content of trichantera leaf meal (TLM) was adjusted to about $12.5 \%$ to match that of the basal diet. This facilitated the replacement of $20 \mathrm{~kg}$ of the basal diet with equal weight of the leaf meal. TLM was mixed with the basal diet. Likewise, FTL was mixed with the basal diet but only upon feeding since it is wet (73\% moisture).

\section{Preparation of leaf meal:-}

The leaves of trichantera were collected from the existing plantation established by the farmer co-operator in a nearby town and from plants in the backyard and fences of her neighbors. The leaf meal was prepared by air drying and sun drying the leaves until brittle and then grinding in a feed grinder which is available at a local feed mill. The dry matter content of trichantera leaves was at about $25 \%$. One metric ton of fresh leaves yielded about $285 \mathrm{~kg}$ TLM 
with $12.5 \%$ of the moisture retained to match the moisture content of the basal diet. The $285 \mathrm{~kg}$ TLM was enough for the whole duration of the experiment.

Table 2:- Nutrient analyses of the feedstuffs used in the experimental diets on as-fed and dry matter bases, and cost per kilogram on as-fed basis

\begin{tabular}{|c|c|c|c|c|c|c|c|c|}
\hline \multirow[b]{2}{*}{ Ingredients } & \multirow[b]{2}{*}{ Basis } & \multicolumn{6}{|c|}{ Component } & \multirow[b]{2}{*}{$\begin{array}{c}\text { Cost } \\
P h p / k g\end{array}$} \\
\hline & & $\begin{array}{c}\mathrm{DM} \\
\%\end{array}$ & $\begin{array}{c}\mathrm{CP} \\
\%\end{array}$ & $\begin{array}{c}\text { Crude } \\
\text { Fat } \\
\%\end{array}$ & $\begin{array}{c}\text { Ash } \\
\%\end{array}$ & $\begin{array}{l}\mathrm{ME} \\
k c a l\end{array}$ & $\begin{array}{c}\text { Crude } \\
\text { Fiber } \\
\%\end{array}$ & \\
\hline \multirow[t]{2}{*}{ Ground yellow corn } & As-fed & 88.7 & 9.00 & 3.90 & 1.3 & 3310.0 & 2.800 & 18.00 \\
\hline & $D M$ & 100 & 10.15 & 4.40 & 1.47 & 3731.7 & 3.157 & \\
\hline \multirow[t]{2}{*}{ Rice bran } & As-fed & 90.9 & 12.40 & 13.3 & 11.5 & 2895.0 & 4.500 & 14.00 \\
\hline & $D M$ & 100 & 13.64 & 14.63 & 12.65 & 3184.8 & 4.950 & \\
\hline \multirow[t]{2}{*}{ Soybean oil meal } & As-fed & 89.0 & 45.00 & 1.50 & 6.5 & 2820 & 6.300 & 20.00 \\
\hline & $D M$ & 100 & 50.56 & 1.69 & 7.30 & 3168.5 & 7.079 & \\
\hline \multirow[t]{2}{*}{ Fish meal } & As-fed & 90.0 & 61.50 & 9.50 & 20.0 & 2635 & 0.900 & 60.00 \\
\hline & $D M$ & 100 & 68.33 & 10.56 & 22.22 & 2927.8 & 1.000 & \\
\hline \multirow[t]{2}{*}{ Molasses } & As-fed & 68.0 & -- & 0.20 & -- & 2265.0 & -- & 12.00 \\
\hline & $D M$ & 100 & 0.00 & 0.29 & 0.00 & 3330.9 & 0.000 & \\
\hline \multirow[t]{2}{*}{ Trichantera leaf meal } & As-fed & 87.5 & 18.83 & 2.45 & 17.2 & 2170.0 & 13.700 & 10.00 \\
\hline & $D M$ & 100 & 21.52 & 2.80 & 19.66 & 2480.0 & 15.657 & \\
\hline \multirow{2}{*}{$\begin{array}{l}\text { Fermented } \\
\text { trichantera leaves }\end{array}$} & As-fed & 27.0 & 5.90 & 0.76 & 5.32 & 766.8 & 2.160 & 3.00 \\
\hline & $D M$ & 100 & 21.85 & 2.81 & 19.70 & 2840.0 & 8.000 & \\
\hline
\end{tabular}

-- not indicated

\section{Fermentation of trichantera leaves:-}

Fresh trichantera leaves were collected daily and then chopped into small pieces for fermentation. Seven plastic drums were used and set up one day after the previous so that a mass of 7-day fermented trichantera leaves was available everyday. Fermentation is done for 7 days with lactic acid bacteria (LAB) as inoculant. Homolactic fermentation by LAB is more desirable than other types of fermentation because the theoretical recoveries of dry matter and energy are greatest (Ennahar et al., 2003). The LAB was bought from an organic farmer at Php150/liter of culture. The LAB was cultured in rice wash and skim milk. The culture solution is diluted at $30 \mathrm{ml} / \mathrm{liter}$ of water and 1tbsp of molasses. The diluted solution was sprayed as the chopped trichantera leaves are being loaded into the drums. The amount of fermented leaves per day depended on the amount needed as indicated in Table 4.

\section{Preparation of the basal diet:-}

The basal diet was formulated with ground yellow corn and rice bran as the major energy sources, and soybean oil meal and fish meal as the major sources of protein. The composition presented in Table 3 was based on as-fed nutrient contents which were computed based on dry matter analysis.

\section{Feeding:-}

Restricted feeding was applied to the experimental animals. The same amount of feed was given to the pigs in all the three treatments based on DM content. On as-fed basis $(87.5 \% \mathrm{DM})$, the amount of feed given was increased by 100 grams every week from 8 weeks up to 14 weeks of age and by 200 grams from 14 weeks to 22 weeks. This is because as the pigs grow older, the weight gain increases and the body requirements for maintenance also increases (Stender, 2012). Since the FTL had a DM content of only $27 \%$ the amount was adjusted for it to provide DM that was the same as the basal diet. The feed was divided into two- one half was given at 6:00 in the morning and the other half at 5:00 in the afternoon. Clean drinking water was made available to the animals at all times. 
Table 3:- Parts by weight in the basal diet formulation and amount of nutrients contributed by each ingredient on asfed basis

\begin{tabular}{|c|c|c|c|c|c|c|c|}
\hline \multirow[b]{2}{*}{ Ingredients } & \multirow[b]{2}{*}{$\begin{array}{c}\text { Part in the } \\
\text { diet } \\
\text { mix } k g / 100 k g\end{array}$} & \multicolumn{6}{|c|}{ Amount of Nutrient from each ingredient per 100kg Mixture } \\
\hline & & $\begin{array}{c}\mathrm{DM} \\
K g\end{array}$ & $\begin{array}{l}\mathrm{CP} \\
k g\end{array}$ & $\begin{array}{c}\text { Crude } \\
\text { Fat } \\
k g\end{array}$ & $\begin{array}{c}\text { Ash } \\
k g\end{array}$ & $\begin{array}{l}\mathrm{ME} \\
\text { kcal }\end{array}$ & $\begin{array}{c}\text { Crude } \\
\text { Fiber } \\
k g\end{array}$ \\
\hline Ground yellow corn & 38 & 33.71 & 3.034 & 1.315 & 0.438 & 1115.7 & 0.944 \\
\hline Rice bran & 35 & 30.91 & 3.832 & 4.110 & 3.554 & 894.7 & 1.391 \\
\hline Soybean oil meal & 11 & 10.68 & 4.806 & 0.160 & 0.694 & 301.2 & 0.673 \\
\hline Fish meal & 10.5 & 9.45 & 5.812 & 0.898 & 1.890 & 249.0 & 0.085 \\
\hline Molasses & 4 & 2.72 & -- & 0.005 & -- & 61.6 & -- \\
\hline Vitamin-mineral mix & 1 & -- & -- & -- & -- & -- & -- \\
\hline Salt & 0.5 & -- & -- & -- & -- & -- & -- \\
\hline Total & 100.0 & 87.46 & 17.484 & 6.488 & 6.577 & 2622.2 & 3.092 \\
\hline
\end{tabular}

-- not indicated

Table 4:- Daily feed allowance of pigs by weekly age.

\begin{tabular}{|c|c|c|c|c|}
\hline $\begin{array}{c}\text { Age } \\
\text { Weeks }\end{array}$ & $\begin{array}{l}\text { Feed Allowance for } \mathrm{T}_{1} \\
k g / d a y\end{array}$ & $\begin{array}{l}\text { Amount of basal diet for } \mathrm{T}_{2} \text { and } \mathrm{T}_{3} \\
k g / d a y\end{array}$ & $\begin{array}{c}\mathrm{TLM}\left(\mathrm{T}_{2}\right) \\
k g / d a y\end{array}$ & $\begin{array}{c}\mathrm{FTL}\left(\mathrm{T}_{3}\right) \\
k g / d a y\end{array}$ \\
\hline $8-9$ & 1.2 & 0.96 & 0.24 & 0.778 \\
\hline $9-10$ & 1.3 & 1.04 & 0.26 & 0.843 \\
\hline $10-11$ & 1.4 & 1.12 & 0.28 & 0.907 \\
\hline $11-12$ & 1.5 & 1.20 & 0.30 & 0.972 \\
\hline $12-13$ & 1.6 & 1.28 & 0.32 & 1.037 \\
\hline $13-14$ & 1.7 & 1.36 & 0.34 & 1.102 \\
\hline $14-15$ & 1.9 & 1.52 & 0.38 & 1.231 \\
\hline $15-16$ & 2.1 & 1.68 & 0.42 & 1.361 \\
\hline $16-17$ & 2.3 & 1.84 & 0.46 & 1.491 \\
\hline $17-18$ & 2.5 & 2.00 & 0.50 & 1.620 \\
\hline $18-19$ & 2.7 & 2.16 & 0.54 & 1.750 \\
\hline $19-20$ & 2.9 & 2.32 & 0.58 & 1.880 \\
\hline $20-21$ & 3.1 & 2.48 & 0.62 & 2.009 \\
\hline $21-22$ & 3.3 & 2.64 & 0.66 & 2.139 \\
\hline Average daily & 2.107 & 1.686 & 0.421 & 1.366 \\
\hline
\end{tabular}

Data Collection and Analysis:-

The pigs were weighed at the start and end of the experiment and the total weight gain was computed by subtracting the initial body weight from the final body weight. The amount of feed given was recorded everyday. Feed consumption was uniform for all treatments since the animals were on restricted feeding. No unconsumed feed was observed throughout the experimental period. Feed efficiency was expressed as the ratio of feed consumption per kilogram liveweight gain. The analysis and cost of each ingredient except TLM and FTL were obtained from the commercial feed mill where purchase was made.

At the end of the experiment, the animals were slaughtered. Dressing percentage was computed by dividing the dressed weight at slaughter by average live weight multiplied by $100 \%$. Backfat thickness including the skin was measured at a point approximately $7.5 \mathrm{~cm}$ from the backbone between the 10th and 11th ribs perpendicular to the skin. Meat samples were brought to the Animal Nutrition Laboratory of the University of the Philippines for the determination of carcass characteristics. The methods used were ashing in a furnace for percent ash, oven method for percent dry matter, Soxhlet extractor method for percent fat, and Kjeldhal distillation method for percent nitrogen and then multiplying by 6.25 to determine percent protein.

One-way analysis of variance (1-w ANOVA) was done for data on total weight gain, average daily gain (ADG), feed conversion efficiency, feed cost per kilogram weight gain, and return above weanling and feed cost. Tukey's test was used for pairwise comparison of treatment means. Data on the other variables were not tested for significant differences because values are either the same for all treatments or the same for all replications within a treatment. 


\section{Results and Discussion:-}

Average measures of pigs' performance under the three treatments by indicators are presented in Table 5. All costs are in Philippine peso (Php).

\section{Weight gain and feed conversion efficiency:-}

The total weight gain of pigs fed with FTL was significantly higher than those fed with basal diet only and those fed with basal+TLM diet. Same comparisons were obtained for ADG and feed efficiency. Feed in $\mathrm{T}_{3}$ had greater bulk as-fed because of the high moisture content (73\%) of the fermented trichantera leaves. This could be a reason for the higher gain of FTL-fed pigs. Maynard et al. (1980) explained that bulk is considered important from the standpoint that a certain distention of the digestive tract is desirable for its most effective functioning particularly in the elimination of feed residue and thus providing space in the digestive tract for the digestion and absorption of more nutrients.

Another reason for higher gain and efficiency of FTL-fed pigs is because fermentation was done with LAB as inoculant. Bacteria are the most important organism that breakdown higher carbohydrates such as cellulose, pentosans and starch. In addition to higher carbohydrate digestion, the organisms synthesize essential nutrients such as amino acids and B-vitamins (Maynard et al., 1980). It is possible that the LAB inoculated during fermentation were carried over to the stomach upon intake and the microbial activity was continued in the digestive tract. The results conform to the report that there was 3\% increase of true protein and 5-10\% reduction of fiber upon fermentation of bagasse (Diaz, 2012). The feed efficiency was better than those observed by Araque (2005) among finishing pigs fed ad libitum with sweet potatoes and tree leaf meals; the values ranged from 3.58 to 5.23.

\section{Feed costs:-}

Feed cost for the three dietary treatments were determined based on the costs of ingredients shown in Table 2 . Lower costs were determined for $\mathrm{T}_{2}$ and $\mathrm{T}_{3}$ because of the inclusion of TLM and FTL. Fresh trichantera leaves are valued at Php2.00/kg and the leaf meal with $87.5 \% \mathrm{DM}$ at Php10.00/kg. The difference of Php8.00 covered weight loss due to drying and the cost of drying and grinding. On the other hand, FTL was Php3.00/kg on wet (73\% moisture) basis which covered the fresh leaves and fermentation costs.

\section{Feed cost per kilogram weight gain:-}

The cost of feed per kilogram of body weight produced was significantly lowest in FTL treatment and highest in pure basal diet. This result was due to the higher feed cost in $T_{1}$ and more efficient conversion in $T_{3}$.

\section{Return above weanling and feed cost:-}

There were significant differences among treatment means of return after deducting the costs of weanlings and feed. The highest return was noted in FLM-fed pigs followed by those fed with TLM.

Table 5:- Indicators of pig performance by treatment and results of analysis indicated by letter superscripts

\begin{tabular}{|l|l|l|l|}
\hline Indicator Variable & Basal Diet & $20 \%$ TLM & $20 \%$ FLM \\
\hline Initial weight (at 60 days old), kg & 11.49 & 11.7 & 11.24 \\
\hline Final weight (165 days old), kg & 79.28 & 78.34 & 82.5 \\
\hline Total weight gain, kg* & $67.79^{\mathrm{b}}$ & $66.64^{\mathrm{b}}$ & $71.26^{\mathrm{a}}$ \\
\hline Number of days of experiment & 98 & 98 & \multicolumn{1}{|c|}{98} \\
\hline Average daily gain, kg* & $0.692^{\mathrm{b}}$ & $0.680^{\mathrm{b}}$ & $0.727^{\mathrm{a}}$ \\
\hline Average daily feed consumption, kg & 2.107 & 2.107 & 2.107 \\
\hline Feed conversion efficiency, kg feed/kg gain* & $3.046^{\mathrm{a}}$ & $3.099^{\mathrm{a}}$ & $2.898^{\mathrm{b}}$ \\
\hline Cost of feed per kg, Php & 23.03 & 20.42 & 20.37 \\
\hline Cost of feed/kg weight gain, Php** & $75.17^{\mathrm{a}}$ & $67.79^{\mathrm{b}}$ & $63.25^{\mathrm{c}}$ \\
\hline Total cost of feed per head, Php & 4755.37 & 4216.44 & 4206.12 \\
\hline Cost of weanlings, Php/head & 2800 & 2800 & 2800 \\
\hline Weanling and feed cost per head, Php & 7555.37 & 7016.44 & 7006.12 \\
\hline Value of the grown-out pigs per head, Php & 8086.56 & 7990.68 & 8415.00 \\
\hline Return above weanling and feed cost, Php** & $531.19^{\mathrm{c}}$ & $974.24^{\mathrm{b}}$ & $1408.88^{\mathrm{a}}$ \\
\hline
\end{tabular}

* Treatment means in a row without common letter are significantly different at $\alpha=0.05(P<0.05)$

** Treatment means in a row without common letter are significantly different at $\alpha=0.01(P<0.01)$ 


\section{Dressing percentage and carcass characteristics:-}

The measurements of dressing percentage and carcass characteristics are presented in Table 6. No significant differences among treatment means were shown by 1-w ANOVA for all the variables measured. The average dressing percentages observed in this study are within what were reported by Jiang et al. (2012) for various crossbreeds with highest at $80.65 \%$ and lowest at $71.68 \%$. Likewise, the backfat thickness values are within the range observed by Jiang et al. (2012) in his study- the highest was $3.54 \mathrm{~cm}$ and the lowest was $1.67 \mathrm{~cm}$. In full-feeding and restricted feeding trials Self (1960) recorded much lower backfat measurements of 1.72, 1.73 1nd 1.52. Backfat thickness is affected by breed (Rybarczyk, 2011), type of feeds, feeding and method of rearing (Heyer, 2004). The percent ash, percent intramuscular fat, crude protein and dry matter content recorded in this study were comparable to those reported by Rybarczyk (2011) which value ranges were 1.12 to $1.21,2.43$ to $2.74,23.43$ to 23.79 and 25.90 to 26.77 respectively collected from five swine crossbreeds.

Table 6:- Dressing percentage and carcass characteristics

\begin{tabular}{|l|c|c|c|}
\hline Variable & Basal Diet & $20 \%$ TLM & 20\% FLM \\
\hline Dressing percentage & 81.53 & 80.82 & 81.77 \\
\hline Backfat thickness, cm & 3.14 & 2.95 & 3.08 \\
\hline Ash, \% & 1.008 & 1.095 & 1.112 \\
\hline Intramuscular Fat, \% & 2.28 & 1.87 & 2.43 \\
\hline Crude Protein, \% & 24.37 & 24.95 & 24.44 \\
\hline Dry matter, \% & 29.15 & 28.33 & 30.16 \\
\hline
\end{tabular}

\section{Conclusion:-}

The study showed that Trichantera gigantea is a promising fodder crop. The leaves are more effective when used in fermented form than in leaf meal form in significantly improving performance of growing-finishing pigs in terms of weight gain and feed conversion efficiency. Both forms have the potential to reduce the cost of feed and therefore increase the income from pig farming. Findings imply that aside from realizing the benefits of improved performance of pigs and economics of pig raising, utilizing trichantera as feed is a form of value adding which itself could be a source of income.

\section{References:-}

1. Aquino, J. T. Jr. and Malazo,M. S. (2005): Cost reduction technology on backyard swine production. 2005. Livestock FITS Center. Department of Agriculture A, ISS III, Sta. Barbara, Pangasinan, Philippines.

2. Araque, H., González, C., Pok, S. and Ly, J.(2005): Performance traits of finishing pigs fed mulberry and trichanthera leaf meals. Revista Científica, FCV-LUZ / Vol. XV, No. 6, 517 - 522, 2005.

3. Costales, A., Delgado, C., Catelo, M.A., Lapar, M.L., Tiongco, M., Ehui, S., and Bautista, A.Z. (2006): Scale and access issues affecting hog producers in an expanding peri-urban market: Southern Luzon, Philippines. IFPRI Research Report, IFPRI, Washington D. C. Forthcoming.pp. 171.

4. Dela Cruz R. T. (2001): Trichantera: cheaper feed substitute to soybean oil meal BAR Digest January-March 2001 Issue (Vol. 3 No.1). Bureau of Agricultural Research, Department of Agriculture, Diliman, Quezon City, Philippines.

5. Diaz, L. A. G. (2012): Improving nutritive value of tropical forages rich in anti-nutritional factors - Some Cuban experiences. Presentation. November 15th, 2012 Symposium 'Fibrous feed resources for livestock in the tropics". University of Ghent.

6. Ennahar, S. Y., Cai, and Fujita ,Y. (2003): Phylogenetic Diversity of Lactic Acid Bacteria Associated with Paddy Rice Silage as Determined by 16S Ribosomal DNA Analysis. Applied and environmental microbiology, Vol. 69, No. 1 p. 444-451.

7. Heyer, A. (2004): Performance, Carcass and Meat Quality in Pigs: Influence of Rearing System, Breed and Feeding. Acta Universitatis Agriculturae Sueciae Agraria 487.

8. Jaya, A.F., Soriano, M.L.L., Vallador, D.M., Intong, R.L. and Carpentero, B.B. (2008): Utilization of madre de agua (Trichanthera gigantea var. Guianensis) leaf meal as feed for growing-finishing pigs. Abstract. Philippine J. Vet. Anim. Sci. 34(2): 117-126.

9. Jiang Y.Z., Zhu, L., Tang, G.Q., Li, M.Z., Jiang, A.A., Cen, W.M., Xing, S.H., Chen, J.N., Wen, A.X., He, T., Wang, Q., Zhu, G.X., Xie,M. and Li, X.W. (2012): Carcass and meat quality traits of four commercial pig crossbreeds in China. Genetics and Molecular Research 11 (4): 4447-4455. 
10. Leterme, P., Botero, M., London, A. M., Bindelle, J. and Buldgen, A. (2006): Nutritive value of tropical tree leaf meals in adult sows. Animal Science 82: 175-182. Q 2006 British Society of Animal Science.

11. Ly, J., Ty, C., Phiny, C. and Preston, T.R. (2001): Some aspects of the nutritive value of leaf meals of Trichanthera gigantea and Morus alba for Mong Cai pigs. Livestock Research for Rural Development 13 (3) 2001.

12. Martens, S.D., Tiemann, T.T., Bindelle, J., Peters, M., Lascano, C. E. (2012): Alternative plant protein sources for pigs and chickens in the tropics - nutritional value and constraints: a review. Journal of Agriculture and Rural Development in the Tropics and Subtropics. Vol. 113 No. 2 (2012) 101-123. urn:nbn:de:hebis:342012092441794 ISSN: 1612-9830 - journal online: www.jarts.info.

13. Maynard, L.A., Loosli, J.K., Hintz, H.F. and Warner, R.G. (1980): Animal Nutrition $7^{\text {th }}$ ed. McGraw Hill Book Company. USA.

14. Philippine Statistics Authority. (2016): Swine Industry Report September 2016. Philippine Statistics Authority, Quezon city, Philippines.

15. Rybarczyk, A., Pietruszka, A., Jacyno, E., and Dvořák, J. (2011): Carcass and meat quality traits of pig reciprocal crosses with a share of Pietrain breed Czech J. Anim. Sci., 56, 2011 (2): 47-52

16. Sarwatt, S.V., Laswai,G.H. and Ubwe, R. (2003): Evaluation of the potential of Trichanthera gigantea as a source of nutrients for rabbit diets under small-holder production system in Tanzania. Livestock Research for Rural Development 15 (11) 2003.

17. Self, R.H.L., Grummer, H., Hays, O.E. and Spies, H.G. (1960):Influence of Three Different Feeding Levels During Growth and Gestation on Reproduction, Weight Gains and Carcass Quality in Swine. J of Animal Science Vol. 19 No. 1, p. 274-282.

18. Shayo, C.M. and Uden, P. (1999): Nutritional uniformity of crude protein fractions in some tropical browse plants estimated by two in vitro methods. Animal Feed Science and Technology, 78, 141-151.

19. Stender, D.R. (2012): Swine Feed Efficiency: Influence of Market Weight. Iowa State University and USDA National Institute of Food and Agriculture. 